2014

\title{
Feminist Aesthetics and Copyright Law: Genius, Value, and Gendered Visions of the Creative Self
}

Carys J. Craig

Osgoode Hall Law School of York University, ccraig@osgoode.yorku.ca

Follow this and additional works at: http:// digitalcommons.osgoode.yorku.ca/olsrps

\section{Recommended Citation}

Craig, Carys J., "Feminist Aesthetics and Copyright Law: Genius, Value, and Gendered Visions of the Creative Self" (2014). Osgoode Legal Studies Research Paper Series. 31.

http://digitalcommons.osgoode.yorku.ca/olsrps/31 


\section{OSGOODE HALL LAW SCHOOL LEGAL STUDIES RESEARCH PAPER SERIES}

Research Paper No. 42

Vol. 10/ Issue. 10/ (2014)

\section{Feminist Aesthetics and Copyright Law: Genius, Value, and Gendered Visions of the Creative Self}

Craig, C. (2014). Feminist Aesthetics and Copyright Law: Genius, Value, and Gendered Visions of the Creative Self. In I. Calboli \& S. Ragavan (eds.),

Protecting and Promoting Diversity with Intellectual Property Law. United Kingdom: Cambridge University Press, forthcoming.

Carys J. Craig

\section{Editors:}

Editor-in-Chief: Carys J. Craig (Associate Dean of Research \& Institutional Relations and Associate Professor, Osgoode Hall Law School, York University, Toronto)

Production Editor: James Singh (Osgoode Hall Law School, York University, Toronto)

This paper can be downloaded free of charge from:

http://ssrn.com/abstract=2464536

Further Information and a collection of publications about Osgoode Hall Law School Legal

Studies Research Paper Series can be found at:

http://papers.ssrn.com/sol3/JELJOUR_Results.cfm?form_name=journalbrowse\&journal_id=722488 
Osgoode Legal Studies Research Paper No. 42

Vol. 10/ Issue. 10/ (2014)

\title{
Feminist Aesthetics and Copyright Law: Genius, Value, and Gendered Visions of the Creative Self
}

Craig, C. (2014). Feminist Aesthetics and Copyright Law: Genius, Value, and Gendered Visions of the Creative Self. In I. Calboli \& S. Ragavan (eds.), Protecting and Promoting Diversity with Intellectual Property Law. United Kingdom: Cambridge University Press, forthcoming.

\section{Carys J. Craig}

\begin{abstract}
:
Copyright law is fundamentally concerned with the value of cultural works-both the recognition and the creation of this value. Yet it is seldom acknowledged that copyright law makes or requires any value judgment in the sense of an aesthetic evaluation of copyright's subject matter. Indeed, it is often emphasized that copyright protects original works of authorship regardless of their quality or merit. That copyright protection demands the satisfaction of only the most minimal of qualitative standards does not, however, dispose of the larger claim that forms the basis of this chapter: our copyright system is dominated by a particular aesthetic theory or idea. Any attempt to justify the rights established by the copyright system over artistic works must presuppose an aesthetic theory of sorts in order to explain what is protected and why (as well as what is not protected or permitted, and why not). While not based on the quality of copyright's subject matter, these explanatory efforts will point to its nature as original literary or artistic expression, which thus deserves or requires some form of legally recognized reward. We simply cannot justify the copyright system without ascribing some value to the particular expressive works in which it vests, and the creative acts and actors that it privileges. Seen in this light, it can hardly be claimed that copyright law is aesthetically agnostic. In this chapter, my goal is to uncover, in copyright's most basic patterns, the hidden aesthetics of copyright law as viewed from a critical feminist perspective. My suggestion is that conceptions of aesthetic value and its production are stitched into the very fabric of copyright law, defining its contours and determining the purposes it serves-and what is more, these conceptions of aesthetic value are fundamentally gendered.
\end{abstract}

\section{Keywords:}

Copyright, aesthetics, originality, authorship, genius, gender, feminism

\section{Author(s):}

Carys J. Craig

Associate Professor

Osgoode Hall Law School

York University, Toronto

E: ccraig@osgoode.yorku.ca 


\title{
Feminist Aesthetics and Copyright Law: Genius, Value, and Gendered Visions of the Creative Self
}

\author{
Carys J. Craig*
}

\section{Introduction}

Copyright law protects works of literature, art, music, and drama. As such, it is fundamentally concerned with the value of cultural works-both the recognition and the creation of this value. Yet it is seldom acknowledged that copyright law makes or requires any "value judgment" in the sense of an aesthetic evaluation of copyright's subject matter. Indeed, it is often emphasized that copyright protects original works of authorship regardless of their quality or merit; after all, anything from blank accounting forms to corporate logos may qualify as protected "works" for copyright purposes. That copyright protection demands the satisfaction of only the most minimal of qualitative standards does not, however, dispose of the larger claim that forms the basis of this chapter: our copyright system is dominated by a particular aesthetic theory or idea. Any attempt to justify the rights established by the copyright system over artistic works must presuppose an aesthetic theory of sorts in order to explain what is protected and why (as well as what is not protected or permitted, and why not). While not based on the quality of copyright's subject matter, these explanatory efforts will point to its nature as original literary or artistic expression, which thus deserves or requires some form of legally recognized reward. We simply cannot justify copyright without ascribing some value and significance to the particular expressive works in which it vests, and the creative acts and actors that it privileges. Seen in this light, it could seem almost audacious to claim that copyright law is aesthetically agnostic.

This book pulls at the many loose threads of our intellectual property system to reveal, amidst the tangle of legal doctrine and complex concepts, the gaps where diverse interests and perspectives are, much like dropped stitches in a blanket, omissions that threaten to ruin the effectiveness and attractiveness of the whole project. In this chapter, my goal is to uncover, in copyright's most basic patterns, the hidden aesthetics of copyright law as viewed from a critical feminist perspective. My suggestion is that conceptions of aesthetic value and its production are stitched into the very fabric of copyright law, defining its contours and determining the purposes it serves - and what is more, these conceptions of aesthetic value are fundamentally gendered.

The chapter proceeds, in Part II, to draw the connections between copyright law and aesthetics in general, and then advances the claim that a particular aesthetic theory-that of romantic aestheticism-dominates our copyright system. Part III describes the author-figure that occupies center-stage in copyright discourse and employs feminist critiques of the concepts

\footnotetext{
*Associate Professor, Osgoode Hall Law School, York University, Toronto.
} 
of "originality" and "genius" to suggest that copyright's protagonist, the romantic author, is not gender-neutral but rather fundamentally patriarchal. Throughout, this discussion implies copyright's complicity in the exclusion and marginalization of women and female creativity in the literary and artistic domain. In Part IV, I survey some of the ways in which feminist aesthetics might disrupt copyright's most central assumptions. Rather than offer a comprehensive account of any particular line of critique and its full doctrinal implications, my aim here is to convey the critical potential of harnessing feminist aesthetic theories and bringing them to bear on copyright law. Not only could this effort enhance the diversity of perspectives represented in the current debates over copyright's future; it could produce a diversification of the interests, values and voices that copyright protects.

\section{Copyright and Aesthetic Judgment}

\section{A. Defining Copyright's Subject Matter}

Copyright protects only original works of an artistic, literary, dramatic, or musical nature. By requiring such classification, the law would seem to demand at least some basic explanation of what is meant by "art," what sounds constitute "music," what symbols, when strung together might be said to amount to "literary" expression. And yet, copyright jurisprudence is replete with the insistence that no such assessment of the substance of a work is required - the determination of whether something is an "artistic work," we are frequently assured, has nothing to do with the qualitative evaluation of whether something is good art, bad art, or even a "work of art." As Alfred Yen put it, "the general irrelevance of aesthetics has become a cornerstone of copyright jurisprudence." " In Bleistein v. Donaldson Lithographing Co., for example, Justice Holmes famously warned, "[I]t would be a dangerous undertaking for persons trained only to the law to constitute themselves final judges of the worth of pictorial illustrations, outside of the narrowest and most obvious limits." "In the House of Lords judgment in George Hensher $v$ Restawhile, Justice Reid wrote of "a trend of authority with which I agree that a court ought not to be called on to make an aesthetic judgment. Judges have to be experts in the use of the English language but they are not experts in art or aesthetics." ${ }^{4}$ In DRG Inc. v Datafile Ltd., Justice Reed warned that "[r]equiring Courts to determine what is 'artistic' ... is not a happy situation," and concluded that the phrase "artistic work" is used in copyright legislation merely "as a general description of works which find expression in a visual medium." ${ }^{6}$ Yet, if the institution of copyright law is indeed aimed at the "progress of the arts"7

\footnotetext{
${ }^{1}$ See, e.g. George Hensher Ltd. v Restawhile Upholstery Ltd. [1976] A.C. 64 (H.L.) 78-9 (U.K.) (Lord Reid stating that "it may be misleading to equate artistic craftsmanship with a work of art. 'Work of art' is generally associated more with the fine arts than with craftsmanship and may be setting too high a standard.").

${ }^{2}$ Alfred C. Yen, Copyright Opinions and Aesthetic Theory, 71 S. CAL. L. REV. 247, 249 (1998).

${ }^{3}$ Bleistein v. Donaldson Lithographing Co. 188 U.S. 239, 251 (1903).

${ }^{4}$ Hensher, [1976] A.C. at 78.

${ }^{5}$ DRG Inc. v Datafile Ltd., [1988] 2 C.F. 243, para. 12 (Can.).

${ }^{6}$ Id. at para. 15 .
} 
and the encouragement of "works of the arts and intellect,", this refusal to give substantive legal definition to "art" might seem strange or troublesome: can we really make, apply, and justify laws that encourage the creation of something we refuse to define?

Alfred Yen has argued convincingly that the judicial insistence upon avoiding explicit aesthetic judgments in copyright cases maintains a perceived distinction between aesthetic and legal reasoning that is entirely illusory; it rests on a particular understanding of the nature of legal reasoning as a rule-bound exercise in formal logic. ${ }^{9}$ A Canadian judge expressly trying to avoid judging the artistic merit of an architectural work nicely captured the connection:

It is gratifying to think that those who drafted this Act were content to leave such aesthetic responsibility to the judiciary, but it is, I think, dangerous to assume such intention. . . . The good art of today is almost invariably the bad Art of tomorrow, for aesthetic standards and values change from generation to generation. ... The legal approach is, as a rule, to elevate precedent and to view innovations somewhat askance. The function of the Judge has always been to weigh evidence and propound existing law. In the arts, evidence of aesthetic values is, as a rule, merely the heated opinion of prejudiced adherents. ${ }^{10}$

Implicit in this passage is the mistaken assumption identified by Yen: "[a]esthetic reasoning is subjective and indeterminate, while legal reasoning is objective and rigorous." To the contrary, Yen argues, "judges necessarily show a preference for certain aesthetic perspectives when they decide cases because copyright law simply requires aesthetic choices." ${ }^{11}$ Consider the need, when establishing copyright protection, to distinguish between artistic works and mere tools or "useful articles;" between "works of artistic craftsmanship" and basic craftwork; and between "sculptures" and any other three-dimensional product. Courts have denied making aesthetic judgments when determining, for example, that furniture prototypes, while pleasing to the eye, are not works of artistic craftsmanship ${ }^{12}$; that colored rods for teaching mathematics, while "attractive," are not artistic works ${ }^{13}$; that color-coded filing labels, while functionally useful, are nonetheless artistic works ${ }^{14}$; that costume helmets, although not actually useful, are not sculptures ${ }^{15}$; that jewelry designs, while primarily for "visual effect," might be more appropriately protected as "industrial designs"; ${ }^{16}$ et cetera.

\footnotetext{
${ }^{7}$ U.S. Const. art. $1, \S 8$, cl. 8 .

${ }^{8}$ Théberge v. Galerie d'Art du Petit Champlain Inc., 2002 SCC 34, at para. 30 (Can.).

${ }^{9}$ Yen, supra note 2, at 249.

${ }^{10}$ Hay \& Hay Constr. v. Sloan, [1957] 27 C.P.R. 132, at para. 5 (Can.).

${ }^{11}$ Yen, supra note 2, at 250.

${ }^{12}$ George Hensher Ltd. v Restawhile Upholstery Ltd. [1976] A.C. 64 (H.L.) (U.K.)

${ }^{13}$ Cuisenaire v. South West Imps. Ltd. [1969] S.C.R. 208 (Can.).

${ }^{14}$ DRG Inc. v Datafile Ltd., [1988] 2 C.F. 243 (Can.).,

${ }^{15}$ Lucasfilm Ltd. v. Ainsworth, [2011] UKSC 39.

${ }^{16}$ Pyrrha Design Inc. v 623735 Saskatchewan Ltd., 2004 FCA 423 (Can.).
} 
Such determinations are not simply the mechanical application of legal rules or established precedent, but require the privileging of one interpretation over a competing alternative interpretation, one precedent over another. In efforts to avoid appearing to judge artistic merit, Yen argues, courts are actually choosing between different aesthetic theories on a case by case basis: they might ask whether contemplating the work produces an aesthetic response in people ${ }^{17}$ (aesthetic formalism); whether a work's creator intended the work to satisfy an aesthetic interest ${ }^{18}$ (intentionalism); or whether a work has been recognized in the artworld as $\operatorname{art}^{19}$ (institutionalism). Simply put, the selection between different approaches to identifying artistic works is, in itself, the expression of an aesthetic preference. ${ }^{20}$

My point is not to decry the presence of aesthetic judgment in legal or judicial decisionmaking. The significance of recognizing the aesthetic judgments in copyright decision-making is to acknowledge the inevitability of aesthetic bias in copyright jurisprudence. For Yen, since "no aesthetic perspective can be neutral and all-encompassing", ${ }^{21}$ the goal is to increase awareness, to manage aesthetic subjectivity, to constrain bias, and to encourage openmindedness. Moreover, by acknowledging that "aesthetically subjective decision making is the only possible approach in copyright cases," and critically evaluating the dominant, purportedly neutral aesthetic bias that has so fundamentally shaped the copyright system. If it is impossible for legal reasoning to separate copyright from aesthetics, the question is "not whether aesthetics should affect copyright law, but how.",23

This is a crucial question to ask when considering the capacity of copyright law to either enhance or limit cultural diversity. Building on Yen's observations, John Tehranian explains that copyright's aesthetic adjudications:

\footnotetext{
${ }^{17}$ See, e.g. Hensher, [1976] A.C. at 78 (Lord Reid stating "If any substantial section of the public genuinely admires and values a thing for its appearance and gets pleasure or satisfaction, whether emotional or intellectual, from looking at it, I would accept that it is artistic although many others may think it meaningless or common or vulgar.").

${ }^{18}$ See, e.g., Cuisennaire v. South West Imps. Ltd. [1968] 1 Ex. C.R. 493 at para. 73 (Noel J. stating, "An artistic work, in my view, must to some degree at least, be a work that is intended to have an appeal to the aesthetic senses... as an important or one of the important objects for which the work is brought into being." See also Hay \& Hay Constr. v. Sloan, [1957] 27 C.P.R. 132, at para. 5 (per Stewart J.: "the tribunal should not attempt to exercise a personal aesthetic judgment but to consider the intent of the creator and its result.")

${ }^{19}$ See, e.g. Hensher, [1976] A.C. at 94, per Lord Simon of Glaisdale: "the most cogent evidence [of whether the subject matter is a work of artistic craftsmanship] is likely to be from those who are themselves acknowledged artist-craftsmen, or from those who are concerned with the training of artist-craftsmen ...".

${ }^{20}$ This degree of choice implies the kind of inherent subjectivity or discretion in judicial decision making that is denied or decried by legal formalists - and has been revealed and trumpeted by critical legal scholars. See John Tehranian, Towards a Critical IP Theory: Copyright, Consecration and Control, 2012 BYU L. REV. 1237.

${ }^{21}$ Yen, supra note 2, at 251.

${ }^{22} I d$. at 301.

${ }^{23} I d$. at 251 , fn 14.
} 
inextricably affect the type of works we, as a society, receive from our artists. ... Even more fundamentally, however, aesthetic judgments can serve to both maintain and preserve existing power structures. The seemingly neutral laws of copyright, therefore, have the potential to create a hierarchy of culture that serves hegemonic interests. ${ }^{24}$

Copyright law does not protect everything. In choosing what to protect, it favors certain forms of artistic and intellectual expression while it restricts or prohibits others. If these choices - these selective protections and prohibitions - are influenced by an underlying but largely invisible aesthetic bias, then a critical legal perspective demands that we ask who it benefits and who it disproportionately burdens, and what role it plays in consolidating existing inequalities. More particularly, from a feminist critical perspective, we might ask, does this aesthetic bias have masculinist underpinnings? Amy Newmann warns that "at least historically, aestheticist thinking has been a vehicle for blatantly masculinist ideologies privileging a certain kind of aesthetic experience . . . arising within male corporeality." 25 If this is so, we might reasonably suspect that copyright's hidden aesthetics maintain and perpetuate a gendered vision of authorship, creativity, and aesthetic worth.

\section{B. Defining Copyright's Threshold: The Aesthetics of Originality}

Copyright emerged in its modern form in the eighteenth century, conferring on the author for the first time a proprietary interest in his text. ${ }^{26}$ It is not by coincidence that this same period saw a fundamental shift in conceptions of authorship in general. In her fascinating book on the evolving conception of plagiarism, Marilyn Randall explains that, while prior to the eighteenth century, imitation had been the aesthetic norm, the eighteenth century saw a "shift from a poetics of imitation to a valorization of originality." 27 Aspirations towards imagination, novelty, creativity, and originality took on great significance in the aesthetics of the Romantic period, which emphasized the individual author and the author-ity that flows from the sincere expression of personal genius. ${ }^{28}$ Romantic aestheticism elevated the artist as individualist: art was "to be created and evaluated in isolation from ethical, social or political considerations - as a pure expression of human nature that bursts forth independently and individualistically." ${ }^{29}$ In this view, true authorship captures the essence of human individuality.

\footnotetext{
${ }^{24}$ Tehranian, supra note 20 , at 1280.

25 Amy Newmann, Aestheticism, Feminism, and the Dynamics of Reversal in AESTHETICS IN FEMINIST PERSPECTIVE 193, 194 (Hilde Hein \& Carolyn Korsmeyer eds., 1993).

${ }^{26}$ See Mark Rose, The Author as Proprietor: Donaldson v Becket and the Genealogy of Modern Authorship, 23 REPRESENTATIONS 51, 54-58 (1988).

${ }^{27}$ Marilyn Randall, Pragmatic Plagiarism: Authorship, Profit AND Power 47 (2003).

${ }^{28} \mathrm{Id}$. at 51.

${ }^{29}$ Newman, supra note 25, at 194.
} 
The well-known words of Justice Homes in Bleistein v Donaldson Lithographing Co. give context to this understanding in the copyright realm: "The [original work] is the personal reaction of an individual upon nature. Personality always contains something unique. It expresses its singularity even in handwriting, and a very modest grade of art has in it something irreducible, which is one man's alone." 30 The distinction between imitation and originality is thus intricately tied to the perception of man's fundamental nature; the man who copies from another sacrifices his authenticity and obscures his intrinsic worth. The valorization of the individual author and his originality, and the resulting denigration of imitation or copying, is axiomatic in modern copyright law. Copyright law, which protects and encourages the creation of "original works," prohibits and discourages copying and the production of unauthorized derivative works.

From its inception with the passing of the Statute of Anne in 1710, modern copyright has vested in authors. An "author" for copyright purposes is no more and no less than the person who originates the expression that copyright protects. If an author is defined by his creation of protectable expression, then the substance of "authorship" is determined by the legal threshold requirement of "originality." The originality standard has been a controversial one across time and place. In the Continental European jurisprudence, it invokes the need for a work to be a "personal intellectual creation"; in the United States, it requires a minimal amount of "creativity"; in the United Kingdom, it demands "skill and labour"; in Canada, it involves something in between creativity and labour, namely, a more than trivial amount of "skill and judgment." 31 Even at its most elevated, the standard thus requires no more than the exercise of some minimum of creative choice, with the result that virtually any work that is not simply copied and involves some degree of choice between different possible options is likely to qualify. Qualitatively, then, the originality determination typically involves little in the way of aesthetic evaluation. But it does not follow that it is devoid of aesthetic assumptions.

Importantly, the very premise of originality under any of these interpretative schools is the origination of a work in the mind of the individual; the expression emanates from him and his intellectual efforts (however unimpressive it may be). It is, then, not because of the quality of their substance but just the sheer fact of their individual origination that original works are thought to merit protection. The work is protected as the "original product of the intellection of a unique individual (or identifiable individuals)." "32 The author who merits protection is "the person who conceives, who expresses ideas, who composes, who creates the work as a result of his labour, his qualities and his personal efforts.",33

\footnotetext{
${ }^{30}$ Bleistein v. Donaldson Lithographing Co. 188 U.S. 239, 249 (1903).

${ }^{31}$ See Elizabeth F. Judge \& Daniel Gervais, Of Silos and Constellations: Comparing Notions of Originality in Copyright Law, 27 CARDOZO ARTS \& ENT. L.J. 375 (2009).

${ }^{32}$ Martha Woodmansee, On the Author Effect: Recovering Collectivity, 10 CARDOZO ARTS \& ENT. L.J. 279, 291-92 (1992) [hereinafter Woodmansee, On the Author].

${ }^{33}$ Ateliers Tango Argentin Inc. v. Festival d'Espagne et d'Amerique Latine Inc. (1997), 84 C.P.R. 3d 56, per Crete J. (trans.); see also Borrow-Giles Lithographic Company v Sarony, 111 U.S. 53, 57-58 (1884) (defining “author" as "he to whom anything owed its origin; originator; maker; one who completes a work of science or literature.").
} 
This conclusion speaks to the essential individuality and mental isolation of the worthy "author" as conceived by copyright law. As Jessica Litman explained, "Our copyright law is based on the charming notion that authors create something from nothing, that works owe their origin to the authors who produce them." ${ }^{34}$ Authorship is constructed in law as an individual moment of creation, where words or notes or actions are born of a largely internal, independent process, making them uniquely the author's. A defining feature of copyright's underlying aesthetic philosophy is, therefore, the objective appreciation of originality, authenticity, and the individuality of the human mind.

A large body of copyright scholarship over the past twenty-five years has sought to demonstrate the presence of a Romantic conception of authorship in the fundamental concepts, principles, and adjudication of copyright law. ${ }^{35}$ Martha Woodmansee, for example, has argued that our intellectual property laws are rooted in the "reconceptualization of the creative process which culminated in high Romantic pronouncements . . to the effect that this process ought to be solitary, or individual, and introduce 'a new element into the intellectual universe." 36 What is more, she suggests, these laws are themselves "one of the most powerful vehicles of the modern authorship construct." 37 James Boyle has warned that the myth of the Romantic author causes us to value some forms of creation over others, and to underestimate the importance of external sources in the creative process. ${ }^{38}$ Mark Rose has decried "the persistence of the discourse of original genius . . . and the reifications of author and work" in copyright law. ${ }^{39}$ For Rose, what emerged out of the nineteenth century and continues to cause difficulties for copyright law todayis "the [romantic] notion of the author as a creative man who by virtue of imposing the imprint of his unique personality on his original works makes them his own."40 The distinction between creative ('productive') and pseudo-creative ('reproductive')

\footnotetext{
${ }^{34}$ Jessica Litman, The Public Domain, 39 EMORY L.J. 965, 965 (1990) (footnotes omitted).

${ }^{35}$ See Martha Woodmansee, The Genius and the Copyright: Economic and Legal Conditions of the Emergence of the 'Author' 17 EIGHTEENTH-CENTURY STUD. 425 (1984) [hereinafter Woodmansee, Genius and the Copyright]; Martha WoOdmansee, The Author, Art and the Market: Rereading the History OF AeSTHETICS (1994); The CONSTRUCTION OF AUTHORShIP: TEXTUAL APPROPRIATION IN LAW AND Literature (Martha Woodmansee \& Peter Jaszi eds., 1994); MARK Rose, AUTHORS AND OWNERS: THE INVENTION OF COPYRIGHT (1993) [hereinafter Rose, Authors And Owners]; Mark Rose, The Author as Proprietor: Donaldson v Becket and the Genealogy of Modern Authorship, 23 REPRESENTATIONS 51 (1988); Mark Rose, The Author in Court: Pope v Curl (1741), 21 CUltural CRITIQUe 197 (1992); see also Molly Nesbitt, What Was an Author? 229 YALE FrENCH STUD. 73 (1987); Carla Hesse, Enlightenment Epistemology and the Laws of Authorship in Revolutionary France, 1777-1793 30 REPRESENTATIONS 109 (1990).

${ }^{36}$ Woodmansee, On the Author, supra note 32 at 291.

${ }^{37}$ Id. at 291 .

38 James Boyle, Shamans, Software AND SPLEENS: LAW AND THE CONSTRUCTION OF THE INFORMATION SOCIETY 51-60 (1996); James D.A. Boyle The Search for an Author: Shakespeare and the Framers, 37 AM. U. L. REV. 625 (1988); see also, Peter Jaszi, Towards a Theory of Copyright: The Metamorphoses of "Authorship," 1991 DUKE L.J. 455.

${ }^{39}$ Rose, Authors and Owners, supra note 35 at 141.

${ }^{40}$ Mark Rose, Mothers and Authors: Johnson v. Calvert and the New Children of Our Imaginations, 22 CRITICAL INQUIRY 613, 614 (1996) [hereinafter Rose, Mothers and Authors].
} 
imagination is integral to all Romantic theorists of art; ${ }^{41}$ it is also integral to copyright law and the line that it draws between the original authorship that is to be encouraged and rewarded, and the unlawful reproduction that is to be prohibited.

\section{The Gendered Author}

\section{A. The Solitary Self}

Of course, the reader may say, nothing in this description of copyright's underlying Romantic aesthetic has any particular relevance to issues of gender or diversity: after all, men have no monopoly on originality. But when it comes to philosophizing about the nature of "mankind" and the ostensibly objective values it entails, feminists have, across decades and disciplines, sought to show how neutral language and "objective" descriptions bear the marks of gender, and so construct hierarchies with gendered significance under the guise of "false universality." 42 The copyright field is no exception. Such feminist critiques are increasingly being brought to bear directly on the seemingly gender-neutral realm of copyright law to problematize, deconstruct, and potentially transform the way in which its core concepts, doctrines, and perceived purposes are understood and realized. ${ }^{43}$

One starting point for a feminist critique of copyright's Romantic aesthetics is to draw the connection between conceptions of authorship and conceptions of selfhood. The authorfigure - this product of the enlightenment era and Lockean notions of self-ownership-is essentially the familiar protagonist of liberal possessive individualism. As Shelley Wright explains:

The existing definition of copyright ... presupposes that individuals live in isolation from one another, that the individual is an autonomous unit who creates artistic works and sells them, or permits their sale by others, while ignoring the individual's relationship with others within her community, family, ethnic group,

\footnotetext{
${ }^{41}$ Christine Battersby, Gender and Genius: Towards a Feminist Aesthetics 145 (1994) [hereinafter BATTERSBY, GENDER AND GENIUS].

${ }^{42}$ Carolyn Korsmeyer, Feminist Aesthetics, THE STANFORD ENCYClOPEDIA OF PHILOSOPHY (substantive revision Nov. 7, 2012) available at: http://plato.stanford.edu/entries/feminism-aethetics (See definition of 'Feminist Aesthetics').

${ }^{43}$ See, e.g., Andrea Abernethy Lunsford, Rhetoric, Feminism, and the Politics of Textual Ownership, 61 C. ENG. 529 (1999); Deborah Halbert, Poaching and Plagiarizing: Property, Plagiarism, and Feminist Futures, in Perspectives on Plagiarism and Intellectual Property in a Postmodern World 111 (Lise Buranen \& Alice M. Roy eds., 1999) [hereinafter Halbert, Poaching]; Malla Pollack, Toward a Feminist Theory of the Public Domain, or Rejecting the Gendered Scope of United States Copyrightable and Patentable Subject Matter, 12 WM. \& MARY J. WOMEN \& L. 603 (2006); Ann Bartow, Fair Use and the Fairer Sex: Gender, Feminism, and Copyright Law, 14 AM. U. J. Gender SOC. Pol'Y \& L. 551 (2006); Dan L. Burk, Copyright and Feminism in Digital Media, 14 Am. U. J. Gender, Soc. Pol'Y \& L. 519 (2006); Dan L. Burk, Feminism and Dualism in Intellectual Property Law, 15 AM. U. J. GENDER, SOC. POL'Y \& L. 183 (2007).
} 
religion - the very social relations out of which and for the benefit of whom the individual's limited monopoly rights are supposed to exist. ${ }^{44}$

This is an important claim because it opens copyright law to an enormous body of critical discourse ranging from the political to the aesthetic, and from the communitarian to the postmodern. Most apt for our purposes here is the critical assertion common to much feminist political theorizing that this fictional liberal self, with its double-edged claim to individuality and universalizability, disguises difference, disregards social "situatedness," and so subsumes and perpetuates a history of domination, subordination, and exclusion. I have argued elsewhere that this mythic individualized author is not only profoundly ideological and historically contingent, but also derives from a strongly gendered vision of the autonomous self: ${ }^{45}$ it truly belongs to what Foucault termed the "fundamental category of "the-man-and-his-work.",46

Feminist and other critical theorists challenge the notion of the subject that underpins this valorization of individuality: the atomized self who transcends society and subjectivity, labors alone, who acquires rights, owns property, calculates rationally, and transacts freely. The core objection is, of course, that " $[\mathrm{t}]$ he place of the free-willed subject who can transcend nature's mandates is reserved exclusively for men." ${ }^{\prime 47}$ If the radically individualized self is the exclusive domain of men, then must not the same be said of the independent, original author at the center of copyright law?

The Lockean individual who appropriates through labor by virtue of his solitary efforts, for example, is a foundational precept in Western property systems, and, I have suggested elsewhere, a persistent specter in our intellectual property discourse. ${ }^{48}$ As Carole Pateman has argued, however, for Locke, "women are excluded from the status of 'individual' in the natural condition." 49 The "masculinist underpinnings" of the Lockean premise of self-ownership are thus imported into copyright's theoretical framework with every invocation of the author's right to "reap what he has sown" and to enjoy the "fruits of his labor." 50 The well-rehearsed feminist critique of the liberal subject readily extends to the idea of the "homo economicus" or

\footnotetext{
${ }^{44}$ Shelley Wright, A Feminist Exploration of the Legal Protection of Art, 7 CAN. J. WoMEN \& L. 59, 73 (1994) (Wright perfectly captures the nature of this relationship, at 73-74).

45 See Carys J. Craig, Reconstructing the Author-Self: Some Feminist Lessons for Copyright Law, 15 AM. U. J. GENDER SOC. POL'Y \& L. 207 (2007).

46 Michel Foucault, What Is an Author?, in THE FouCAUlt READER 101 (Paul Rabinov, ed., 1984) (Emphasis added.).

47 Linda Alcoff, Cultural Feminism Versus Post-Structuralism: The Identity Crisis in Feminist Theory, in FEMINISM AND PHILOSOPHY: ESSENTIAL READINGS IN THEORY, REINTERPRETATION, AND APPLICATIONS 434, 435-6 (Nancy Tuana \& Rosemarie Tong eds., 1995).

${ }^{48}$ See Carys J. Craig, Locke, Labour, and Limiting the Author's Right: A Warning Against a Lockean Approach to Copyright Law, 28 QUEEN's L.J. 1 (2002).

49 See CARen Irr, Pink Pirates: Contemporary AMERICAN Women Writers AND Copyright, 23 (2010) quoting CAROLE PATEMAN, THE SEXUAL CONTRACT 52 (1988).

${ }^{50}$ See id.
} 
"economic man"51 who dominates copyright's increasingly utilitarian narratives. As feminist theorists have shown, the universal subject of the neo-classical economic model-the unencumbered subject who makes rational calculations on the basis of self-interest - similarly excludes considerations of human relations, situation, and power. Once revealed, the positionality of the homo economicus (who most closely resembles the privileged white, male, heterosexual elite) suggests that "economic rationales are often merely a way to preserve the patriarchal status quo." 52 Might the same be said when copyright is justified on the basis that authors, cast in the role economically rational actors, create in response to the incentives offered by copyright protection $?^{53}$

For the common law copyright system, whose justifications so depend on the vision of the industrious, deserving, and rational author, such a conclusion goes to the very heart of the system, how it works, and who it privileges. Deborah Halbert and other feminist copyright scholars, building on such theoretical critiques, have sought to show their practical ramifications by pointing to particular forms of gendered creative practice excluded from copyright's domain by virtue of their misalignment with the solitary authorship trope. Thus, for example, the preparation of food and the fabrication of clothing, both traditionally women's work relegated to the domestic realm, have existed largely outside of the intellectual property paradigm, ${ }^{54}$ as have the products of shared creative practices such as quilting and knitting. ${ }^{55}$ Collaborative and collective projects, whether based on relationships of care or born of functional necessity, have been marginalized or problematized by the model of individual, commodified intellectual production — usually with gendered implications. ${ }^{56}$

The distinction between fine art and crafts has been a particular focus of feminist critique. The very concept of art was narrowed to include works produced purely for their aesthetic virtues, and thus distinguished from arts produced for practical use, which came to be designated as "crafts." Making craftworks, though skillful, was not regarded as possessing the same order of originality. Thus traditional domestic arts, predominantly the domain of women,

${ }^{51}$ See Elizabeth Mayes, Private Property, the Private Subject, and Women: Can Women Truly Be Owners of Capital?, in FEMINISM CONFRONTS Homo ECONOMICUS: GENDER, LAW \& SOCIETY (Martha Albertson Fineman \& Terence Dougherty eds., 2005).

${ }^{52} I d$. at 58.

${ }^{53}$ See, e.g., William M. LANDES \& Richard A. POSNER, THE ECONOMiC STRUCTURE OF INTELLECTUAL Property LAW (2003).

${ }^{54}$ See, e.g., Pollack, supra note 43.

${ }^{55}$ See, e.g., Deborah Halbert, Feminist Interpretations of Intellectual Property, 14 AM. U.J. GENDER SOC. POL'Y \& L. 431 (2006). See also Wright, supra note 44 at 90-4, 96; Bartow, supra note 43 at 573; Boatema Boateng, Authoring Cloth: The Copyright Protection of Fabric Designs in Ghana and the U.S., in AUTHORSHIP AND MEDIA 87 (Cynthia Chris \& David Gerstner eds., 2013); Estella Lauter, Re-enfranchising Act: Feminist Interventions in the Theory of Art, in AestheTICS IN FEMINIST PERSPeCtive 21, 24 (Hilde Hein \& Carolyn Korsmeyer eds., 1993) ("The genre of quilts has been gendered in a straightforward way. The traces of 'feminity' . . form the likely basis for their categorical exclusion.")

${ }^{56}$ See Peter Jaszi \& Martha Woodmansee, The Ethical Reaches of Authorship, 95 S. ATLANTIC Q. 947, 967-68 (1996). 
came to be excluded from the realm of art and the records of art history. ${ }^{57}$ Indeed, such was the gendered impact of this "formalist condemnation of the utilitarian" that it might reasonably be

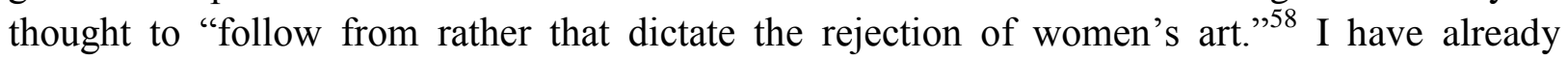
suggested that the distinction between "artistic works" and utilitarian works of craftsmanship represents an important boundary in the legal limits of copyright protection governed by a hidden aesthetics. To the extent that the arts-craft boundary disproportionately excluded women from public recognition in the visual arts, copyright's boundaries compounded this exclusion by withholding the benefits of legal protection.

At a more abstract level, the very idea of the transcendent, independent author and the romantic aestheticism that he embodies has also been the target of feminist aesthetic theorists. An aesthetic theory that takes as its starting point the artist as unencumbered, universal individual, must fail to appreciate not only the nature of the creative process, but also the aesthetic value of the creative work. Estella Lauter explains:

Art is not produced in a rarefied atmosphere that transcends gender identification. We create as men and women who are influenced by biological and imaginative mothers and fathers. Far from being a set of discrete, autonomous art objects, art is deeply contextual . . . [with] multiple relationships to its contexts. 59

Art, then, or the "work" in copyright terms, is not autonomous; it must be seen in context, as socially and culturally situated, and not as the free-standing, stable product of a transcendent author. So let us turn now to consider the ways in which these gendered assumptions about the individuality of the author have informed our aesthetic evaluations of the author's work (and worth), and our conceptualization of the author-work relationship.

\section{B. The Gender of Genius}

In the nineteenth century, Marilyn Randall explains, the concept of individual authorship was compounded by the "great author" phenomenon: originality was the mark of an individual's genius. A great author was a "great soul emitting inspired and universal truths,"60 while lesser humans could merely follow suit by learning, imitating, and borrowing. While I have stressed the masculinist detachment of the originating author-genius, it is interesting to note that this romantic instantiation of "genius" is just one in an evolving progression of

\footnotetext{
${ }^{57}$ See Korsmeyer, supra note 42 citing RozsiKa PARKER \& GRISElda POLlack, Old Mistresses: Women, ART AND IDEOLOGY (1981).

${ }^{58}$ See Lauter, supra note 55 at 24.

${ }^{59} \mathrm{Id}$. at 27.

${ }^{60}$ RANDALL, supra note 27 at 54.
} 
competing conceptualizations of genius over time. Christine Battersby, describing the "gendering of genius" suggests that every iteration of the author-genius, from the pre-modern to the post-modern, has hailed whatever characteristics women were believed, at that time, to most lack (whether it be passion, reason, madness, or even, most recently, the willingness to discard the claim to subjective authority). ${ }^{61}$ Thus, genius has consistently been defined in contradistinction to the feminine. For example, in the Renaissance period, women were thought to be too creative and so not sufficiently capable of perceiving objective truth to qualify for the label of genius. ${ }^{62}$ For Jean-Jacques Rousseau, writing in the mid- $18^{\text {th }}$ century, the basis for claiming that "women, in general, possess no artistic sensibility . . nor genius" was that women's writings are "as cold and pretty as women; . . . they are a hundred times more reasoned than impassioned." ${ }^{63}$ Women's failing, then, was a deficiency in passion. Immanuel Kant, for whom Rousseau was a great hero, wrote his own treatise on aesthetics and the sublime, ${ }^{64}$ which also explicitly excluded women from ranks of genius, now on the basis that woman are passionate creatures whereas genius is a matter of reason. ${ }^{65}$ For Kant, women's overriding duty was to be beautiful, to pursue feminine qualities of grace, charm, domesticity. The pursuit of knowledge or deep (as opposed to beautiful) understanding was therefore defeminizing. The woman who knows Greek or mechanics "might as well even have a beard," he wrote, and the woman who succeeds in laborious learning "destroy[s] the merits that are proper to her sex." 66 Sublime pleasure, meanwhile, was "closed off to all except the "moral man." 67

Battersby emphasizes that creative women today face problems that derive directly from a Romantic inheritance-a Romantic aesthetics that built on Kantian epistemology and produced a conception of genius that is particularly harmful to women:

Our present criteria for artistic excellence have their origins in theories that specifically and explicitly denied women genius. We still associate the great artist with certain (male) personality-types, certain (male) social roles, and certain kinds of (male) energies. ... Women who want to create must still

\footnotetext{
${ }^{61}$ BATTERSBY, GENDER AND GENIUS, supra note 41 at 113.

${ }^{62}$ Id. at 48 .

63 Jean-Jacques Rousseau, Letter to Mr d'Alembert, in Marcia J. Citron, Women and the Lied, 1775-1850, in Women Making Music: The Western ART Traditions, 1150-1950 224, 225 (Jane Bowers \& Judith Tick eds., 1986) (cited in BATTERSBY, GENDER AND GENIUS, supra note 41 at 50).

${ }^{64}$ IMMANUEl KANT, THE CRITIQUE OF JUDGMENT (W.D. Pluhar trans., Hackett, 1987) (1790).

${ }^{65}$ BATTERSBY, GENDER AND GENIUS, supra note 41 at 113.

${ }^{66}$ ImMANUEl KANT, OBSERVATIONS ON THE FEELING OF THE BEAUTIFUl AND Sublime 78 (John T. Goldthwait trans., University of California Press, 1960) (1764) (cited in BATTERSBY, GENDER AND GENIUS, supra note 41 at 112).

${ }^{67}$ Christine Battersby, Stages on Kant's Way: Aesthetics, Morality, and the Gendered Sublime, in FEMINISM AND Tradition In Aesthetics 88, 95 (Peggy Z. Brand \& Carolyn Korsmeyer eds., 1995) cited by Anne Barron, Feminism, Aestheticism and the Limits of the Law, 8 FEMINIST LEGAL STUD. 275, 285 (2000) (arguing that Kantian aesthetics can nonetheless be re-appropriated by feminist legal theorists).
} 
manipulate aesthetic concepts taken from a mythology and biology that were profoundly anti-female. ${ }^{68}$

To the extent, then, that copyright law has maintained and incubated this great artist figure in its rationale and rhetoric, this is a damning indictment of copyright indeed. It surely strikes at the core of our copyright structures to concede that " $[\mathrm{t}]$ he origins of intellectual property law, authorship, originality, and plagiarism are indebted to understanding creation as the domain of males who are the only ones authorized to speak and write." 69

Throughout her fascinating book, Battersby advances that argument that genius itself is male ${ }^{70}$ and constructs the powerful claim that the Romantic notion of genius has consistently been wielded "to try and beat back the female hordes invading the male space of European culture." ${ }^{71}$ What makes this perhaps most indicative of a continually shifting and evolving cultural misogyny, she argues, is that Romanticism elevates precisely those attributes that were previously downgraded as "feminine" (emotionality, sensitivity, spontaneity, self-expression); but what is seen as natural imperfection in women is regarded as accomplished perfection in a man.

For Battersby, the most egregious or ironic of these male misappropriations of feminine attributes as indicators of exclusively male genius, is the concept of author as mother - or, as she describes it, the metaphor of "male motherhood," which became increasingly common over the $19^{\text {th }}$ century: "The artist conceived, was pregnant, labored (in sweat and pain), was delivered, and (in an uncontrolled ecstasy of agonized - male-control) brought forth. These were the images of "natural' childbirth that the male creators elaborated."72 This tendency reached its climax in the writings of Friedrich Nietzsche, for whom a genius was "one who either begets or gives birth spiritually," while an average man who failed to create thus failed to become "a 'mother' type in the grand sense," but rather resembled "an old maid." 73 For Nietzsche, however, a woman who "dabbled" in art lost "her instincts,",74 and her education "defeminized" her. ${ }^{75}$ These representations of genius and creativity thus commandeered, for male creators, inherently female attributes, while simultaneously constricting women's creative capacities to the physical act of procreation. Battersby offers the words of Frank Barron, a lauded expert on the psychology of creativity, as a more recent textual example that underscores this ironic exclusion:

\footnotetext{
${ }^{68}$ BATTERSBy, GENDER AND GENIUS, supra note 41 at 32.

${ }^{69}$ Halbert, Poaching, supra note 43 at 117.

${ }^{70} \mathrm{Id}$. at 94.

${ }^{71}$ Id. at 106.

${ }^{72}$ Id. at 107.

73 FrIEDRICH NEITZSCHE, BEYOND GOOD AND EVIL $\$ \$ 206,369$ (Walter Kauffman trans., Vintage 1966) (1886) cited in BATTERSBY, GENDER AND GENIUS, supra note 41 at 176.

74 FrIEDRICH NeITZSCHE, The WILl to Power (Walter Kauffman ed., Vintage, 1968) cited in BATTERSBY, GENDER AND GENIUS, supra note 41 at 177.

${ }^{75} I d$. at $\$ 239$.
} 
The creative act is a kind of giving birth, and it is noteworthy that as an historical fact intellectual creativity has been conspicuously lacking in women, whose products are their children. At the risk of making too much of a linguistic parallel, it might be said that nature has literally arranged a division of labour. Men bring forth ideas, paintings, literary and musical compositions . . . while women bring forth the new generation. ${ }^{76}$

As Mark Rose reminds us in his insightful article on "Mothers and Authors," the analogy of authorship to procreation invokes the gendered mind/body (male/female, intellect/matter) dichotomy, with the necessary implication that "authorship is a gendered category."77 Rose notes that the author's right, in copyright law, to have his name attached to a work he created is known as the "right to paternity." "A8 Authorial attribution is the right to be identified and to so protect the patrilineal line, as it were. Indeed, copyright is replete with parental metaphors: the author "originates," "creates," and "labours"; he acquires rights of "reproduction"; he defends his propriety with claims of "independent creation"; when his identity is unknown, his work is described as "orphaned." The filial relation represents the origin and legitimacy of the intellectual offspring, and the rightful claims of the author-parent. The presence of these metaphors within copyright's most fundamental doctrines should alert us to the gendered nature of copyright. It should also provoke us to ask what work these concepts are doing in shaping the development of the law and its application.

William Patry has also rued the "creation-as-birth" metaphor and, in particular, the way in which is wielded in the copyright domain to suggest that authors should enjoy extensive control over their works. ${ }^{79}$ In urging the passage of the Statute of Anne, Daniel Defoe declared: “A Book is the Author's Property, 'tis the Child of his Inventions, the Brat of his Brain; ... 'tis as much his own, as his Wife and Children." ${ }^{80}$ We see here the ideological link of the Romantic author-genius to the author-owner who features so prominently in modern copyright discourse: copyright's protagonist is a surviving figure of "patriarchal domesticity; the author as master of his household." ${ }^{, 81}$ The relationship conjured between the male author-mother and the text-child is not one of nurturing, maternal love, but paternal ownership combined with the power of market alienation. The oft-quoted words of Nathaniel Shaler exemplify this link between paternity and property: "The man who brings out of the nothingness some child of his thought, has rights therein which cannot belong to any other sort of property." 82 The common merging of

\footnotetext{
${ }^{76}$ FrANK BARRON, CREATIVITY AND PERSONAL FREEDOM (1968).

${ }^{77}$ Rose, Mothers and Authors, supra note 40 at 623.

${ }^{78} I d$.

${ }^{79}$ William Patry, Moral PANics AND the COPYRight Wars 69-70 (2009).

${ }^{80}$ Rose, AUTHORS AND OWNERS, supra note 35 at 39.

${ }^{81}$ Mark Rose, Copyright and its Metaphors, 50 UCLA L. REv. 1, 5 (2002) [hereinafter Rose, Copyright and its Metaphors].

${ }^{82}$ Id. at 9 (quoting NATHAN SHALER, CONSIDERATIONS ON THE NATURE OF INTELLECTUAL PROPERTY AND ITS IMPORTANCE TO THE STATE 9 (1878)).
} 
the (ostensibly incompatible) childbirth and property metaphors, still characteristic of much modern day copyright rhetoric, can be understood only when seen through the prism of patriarchy.

From a feminist perspective, of course, the childbirth metaphor could be reimagined to yield alternative conclusions about the relationship of author to text. Rather than a bond based on single-sexed origination, patrilineal lineage, and enduring control, childbirth for the biological mother requires an inevitable letting go: the cutting of the umbilical cord, nurturing, raising and preparing the child to go out into the world, to speak on its own behalf, to interact and form relations with others, to have children of its own. Perhaps, then, the creation-aschildbirth metaphor can be used critically to reimagine the relationship between author and text, and between texts in the ongoing process of cultural creation. Mark Rose makes a similar argument by emphasizing, rather than the relationship of mother and child, the modern understanding of human genetics:

[T] he paternity metaphor obscures the fact that literary works are the products of complex collaborations in which many individuals are involved . . . , and that literary works are produced through acts of generation that involve the adaptation and transformation of materials from the literary gene pool rather than creation out of nothingness. . . . The paternity metaphor is patriarchal and obsolete. More significantly, the entire conception of authorship embedded in the paternity trope is obsolete. We need a better biology of authorship. ${ }^{83}$

Either conceptual approach is an attempt to disrupt the "male motherhood" metaphor that shaped Romantic conceptions of genuine authorship, and pervaded legal discourse in the justification of authors' rights. Both illustrate the way in which copyright law, freed from gendered notions of authorship and genius, might evolve to better reflect the processes of intellectual creativity and the dynamic nature of the text.

\section{A Feminist Aesthetics for Copyright Law?}

I have suggested, in the preceding sections, that copyright law is not aesthetically neutral, despite common claims that it demands no aesthetic evaluation of the works to which it extends. I have argued that, in fact, copyright law is dominated by a Romantic aestheticism that venerates originality and denigrates derivative expression. I have also shown, I hope, that copyright's dominant aesthetic theory, and the implicit assumptions about creators and their works that it generates, are not neutral or gender-free. In fact, the trope of romantic authorship and the related idea of "genius" are radically gendered - and the notion of the author-genius as rightful owner is fundamentally patriarchal. If copyright's protagonist is revealed to be a

${ }^{83}$ Rose, Copyright and its Metaphors, supra note 81 at 14-5. 
surviving figure of patriarchal mythology, and if the structures of copyright law were developed to reward and encourage his efforts, then perhaps the feminist must conclude that copyright law is simply "rotten to the core;" it cannot be redeemed but must be discarded.

At best, the feminist must concede that copyright law, in its modern form, was a law written by men, for men. Certainly, in copyright's formative era, the powers that it granted vested in male authors. By refusing most women the legal status or benefits of proprietors, the law denied most female authors the proprietary relationship with their texts enjoyed by their male counterparts. ${ }^{84}$ The practical distance thus produced between women's creative practices and the market may also have produced, in a sense, a psychological distance, a space of resistance, between the cultural creativity and its commoditization. ${ }^{85}$ Regarded in this way, it would not be surprising to find that women's relationship to their texts acquired a different hue - one that is not accurately reflected in the proprietary structures of control maintained by the copyright system. Anne Bartow captures this idea powerfully when she states: "Copyright laws were written by men to embody a male vision of the ways in which creativity and commerce should intersect." 86

And so, it remains to be asked, how might a feminist aesthetic be brought to bear in the copyright realm to challenge and change the way in which the law now regulates creative expression? To be clear, there is no unified definition or substance to the category of feminist aesthetics that could produce a single answer to such a question. Rather, it embraces a wide array of perspectives that seek, in various ways, to question seemingly gender neutral philosophical theories and assumptions about art and aesthetic categories, ideas about artists and aesthetic value, and the influences of power in the social formation of the situated subject. ${ }^{87}$ As this would suggest, the avenues of possible critique in the field of copyright law are manifold, and their potential implications are as diverse as the perspectives that inform them.

So, for example, copyright's subject matter categories could be critically examined on the basis of the works that they privilege as part of copyright's "core," and those that they marginalize or exclude. Consider, again, how copyright has tackled the categorization of "artistic works" when troubled by the utilitarian products lurking at the margins. As Yen demonstrated, it has done so by employing (while denying) the use of traditional aesthetic theories. An approach grounded in traditional "formal" aesthetics might ask whether the work generates an aesthetic response in people; feminist theorists might ask, "what people?", and challenge the notion of art as autonomous from moral or political concerns. After all, aesthetic responses, tied up as they are with judgments of beauty, have tended to assign women the role of bearers of meaning under the male gaze, rather than makers of meaning. A feminist "reception theory" would instead seek to understand the art's relationship to its cultures - the

\footnotetext{
${ }^{84}$ Melissa J. HOMESTEAD, AMERICAN WOMEN AuthorS AND Literary PROPERTY, 1822-1869 3 (2005).

${ }^{85}$ Id. See also Irr, supra note 49, at Chapter 1.

${ }^{86}$ Bartow, supra note 43 at 557.

${ }^{87}$ See Korsmeyer, supra note 42.
} 
political, social, religious, economic, and aesthetic responses that it generates - rather than to define it within categories. ${ }^{88}$ A traditional "intentionalist" approach would inquire into the purposes of the work's creator; a feminist theorist might ask why the function of covering a bed, for example, is less worthy than the function of achieving professional accolades or making money. ${ }^{89}$ Whose purpose is privileged, and when can art transcend purpose? An "institutionlist" aesthetic theory might be brought to bear to examine whether a work is accorded the status of art in the artworld; a feminist aesthetics would reveal that "work by women that seems identical in value to work by men may not be [considered] art (or good art) when the artworld's filters contain social biases about women along with precepts about art."90

In this way, it becomes evident, I think, that using feminist aesthetics to problematize the underlying assumptions at work in defining copyright's categories could challenge some of copyright's exclusionary ideals and practices, and precipitate a re-evaluation of many forms of expression that are relegated to copyright's margins or excluded from its protective sphere as art's Other. Similarly, the use of feminist aesthetic theories to unsettle ideas of independent creation could offer new ways of thinking about and assessing standards of "originality." Whereas courts traditionally look for the absence of copying as the sine qua non of legal protection, a feminist approach that "returns art to its social contexts," in which even identical reproductions can resituate prior works, lending them "new" meanings across space and time. Deconstructing the Romantic division between origination and imitation could thus suggest alternative standards for measuring expressive worth and assessing the need for encouragement and protection. For example, feminist aesthetics, which also emphasizes the connections within and between communities of artists, might support a more relational approach to the originality determination - one that views the work, not in isolation, but in dialogic relation to the other works on which it is based or to which it responds. ${ }^{92}$ And, of course, by dismantling the myth of solitary authorship, feminist aesthetics would pave the way to a new appreciation and valorization of art produced cooperatively, collaboratively, or collectively (whether in concert or separated by space and time). ${ }^{93}$ Broadly speaking, in the copyright domain, as elsewhere, "with the help of feminist aesthetics we are able to appreciate old things in new ways and to assimilate new things that would be excluded by traditional aesthetic theory." $" 94$

The intent here, it should be stressed, is not to extend copyright to cover more forms of expression (and so to impose more expressive limits on others). Just as the critical enterprise of

\footnotetext{
${ }^{88}$ Lauter, supra note 55.

${ }^{89}$ Id. at 23.

${ }^{90} \mathrm{Id}$. at 25.

${ }^{91}$ Id. at 33 .

92 See CARYs J. CRAIG, Copyright, COMMUnity AND CUlture: TOWARDS A RElATIONAL THEORY OF COPYRIGHT LAW 139-41 (2011).

${ }^{93}$ See Lauter, supra note 55 at 30.

${ }^{94}$ Hilde Hein, The Role of Feminist Aesthetics in Feminist Theory in FEMINISM AND TRADITION IN AESTHETICS 446, 455 (Peggy Z. Brand \& Carolyn Korsmeyer eds., 1995).
} 
feminist aesthetics does not stand or fall by proving some kind of parity with male literary or artistic "genius," a feminist critique of copyright does not succeed or fail with its ability to extend the privileges of copyright protection to more women authors or predominantly female creative practices. Rather, by bringing feminist aesthetics into the heated debates around copyright law, we can critically re-evaluate the theoretical underpinnings of a copyright system based on gendered assumptions about creativity, economic reward, exclusion, and control.

\section{Conclusion}

Our copyright system is not aesthetically agnostic. Its willingness to protect the most mundane of works is not a basis on which to conclude that the law makes no aesthetic judgment. Nor is the fact that copyright attaches to "every original literary, dramatic, musical and artistic work" a reason to believe that the extraordinary protections it affords are neutral and unbiased. In fact, the reach — and the very rationale — of copyright are informed by the aesthetic theories that dominated at its inception and prevailed throughout its most formative years. Copyright's commitment to independent origination, its conception of protectable subject matter, its insistence upon proprietary reward-all the most fundamental assumptions stitched into the complex quilt of copyright — are cut from the cloth of romantic aestheticism.

For the copyright theorist, this suggests the need to critically reevaluate copyright's norms and effects through an interdisciplinary lens. It demands that we draw on insights from the fields of aesthetics and the philosophy of art, literary and music theory, for example, to problematize and ultimately improve the law's understanding of the creative self, expressive practices, and intellectual products. For the feminist theorist, however, the recognition of copyright's dominant aesthetic theory also reveals its inherently gendered nature, suggesting the need to identify and disrupt the masculinist assumptions and patriarchal structures supported and preserved by the legal construct of copyright. It demands that we focus our interdisciplinary lens on the critical feminist insights and activities that have disrupted and deconstructed conventional knowledge and practice across disciplines. In particular, as I have argued here, a turn towards the field of feminist aesthetics could bring the promise of a quite radically reimagined copyright system. If we remain within the horizons of the Romantic myth, however, we will only be able to progress so far. ${ }^{95}$

\footnotetext{
95 See BATTERSBY, GENDER AND GENIUS, supra note 41 at 153 ("If we remain within the horizons of the Romantic myth - that takes male reason, male fantasies and male sexual energies as the norms for creativity - women will only be able to progress so far.").
} 